\title{
「東南アジア古生物の研究」についての記録
}

\author{
東南アジア古生物研究会
}

\section{Record of a Palaeontological Research in Southeast Asia}

Association of Palaeontological Research in Southeast Asia

はじめに

昭和37年（1962年）に我々の東南アジア古生物の研究が始まつてから約 8 年が経過し，その間に 6 回の 現地調查が実施され，その成果は “Geology and Palaeontology of Southeast Asia” (東大出版会刊行) に逐次発表されつつあり，第 8 巻までに89論文およびタイ・マレー・フィリッピンの地質あるいは古生物 についての既知の記録の総括 4 篇が公表された。昭和 42 年 (1967年) 春，このプロジェクトに参加してい る研究者によつて「東南アジア古生物研究会」が組織され, 作業が進められることになつた。現在(1971年 1 月), 会員数注 61 名, 内, 海外会員は 18 名である。

本稿はプロジェクト全体についての目的・構成・調查地域などの記録の総括であり, 現地調查でえられ た学術上の問題については, 別の機会に総括する。

\section{I. 研究題目および調査隊員 (○印, 研究代表者)}

第 1 次 : 昭和37年度（1962 63年）; “タイ国古生物調查”

○小林貞一(東大), 橋本 亘(東教大), 鳥山隆三(九大), 勘米良亀齢(九大), 佐藤 正(東大) 〔以上 5 名]

第 2 次 : 昭和38年度（1963 64年）；コロンボ計画による“マレーシア・タイ国派遣古生物および地層 調查”

○小林貞一(東大), 岩井淳一 (東北大), 鳥山隆三(九大), 木村敏雄(東大), 佐藤 正(東大), 浅間一 男 (国立科博)，浜田隆士(東大)，猪鄉久義 (目白女子短大) [以上 8 名]

第 3 次 : 昭和 39 年度 (1964 65年); “東南アジア古生物の研究”

○鳥山隆三 (九大), 勘米良亀䶕 (九大), 首藤次男 (九大), 柳田寿一(九大), 猪郷久義 (目白女子短大),

浜田隆士 (東大), 浅野 清(東北大), 金谷太郎(東北大), 高柳洋吉(東北大), 小林貞一(東大) [以 上10名]

第 4 次 : 昭和 40 年度（1965 66年）; “東南アジア古生物の研究”

○鳥山隆三 (九大), 岩井淳一 (東北大), 橋本 亘(東教大), 木村敏雄 (東大), 佐藤 正(東大), 勘米 良亀噛(九大), 菅野三郎 (東教大), 田村 実(熊大), 坂上澄夫 (北海道学芸大), 猪郷久義 (目白女子 短大), 柳田寿一(九大), 徳山 明(東大), 北村 信 (東北大) 〔以上 13 名〕

第 5 次 : 昭和 41 年度 $(1966 \sim 67$ 年) ; “東南アジアの比較層序学的研究”

○浅野 清(東北大), 北村 信 (東北大), 小高民夫(東北大), 橋本 亘(東教大), 菅野三郎(東教大),

木村敏雄 (東大), 小西健二(金沢大), 佐藤 正(東大) [以上 8 名]

第 6 次 : 昭和43年度（1968 69年）; “東南アジアに発達する赤色盈地の地史学的古生物学的研究”

○鳥山隆三(九大), 岩井淳一(東北大), 橋本 亘(東教大), 浅間一男 (国立科博), 藤山家徳 (国立科

博), 氏家 宏 (国立科博), 坂上澄夫(愛媛大), 田村 実(熊大), 首藤次男 (九大), 柳田寿一(九

大), 小沢智生 (九大), 猪郷久義 (東教大), 小池敏夫（九大） [以上 13 名] 


\section{II. 目的国および調査費}

第 1 次〜第 6 次の現地調查を実施した国名と調查費を第 1 表に示す。

第 1 表

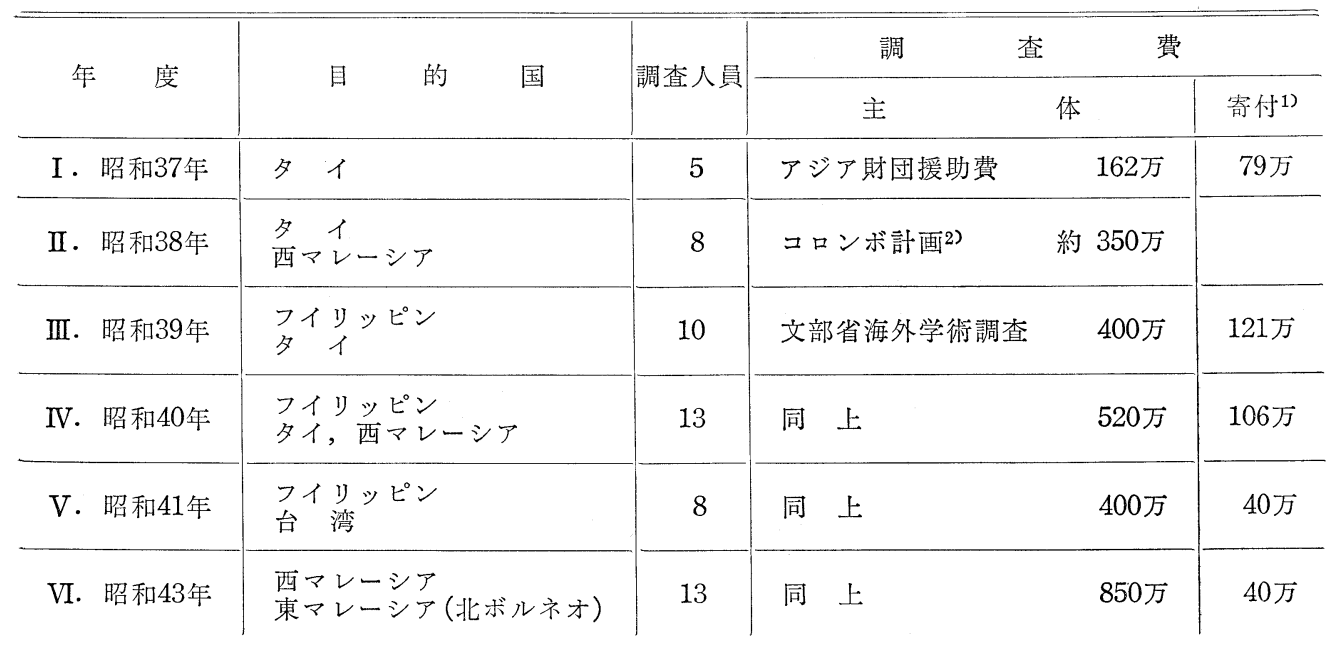

1）第 3 次〜第 5 次の文部省海外学術調查費では調查費総額の $10 \sim 20 \%$ 寄付金で賄う ことが義務ずけられていた。また現金以外に若干の現物寄付がある。

2）コロンボ計画では相手国もほぼ同額の費用を負担している。

\section{III. 協力機 関}

外地における地質調查注言語・慣習上の問題などがあるので，現地の公的機関の協力なしに行なうこと は殆んぞ不可能といつてよい。このプロジェクトにおいても下記の相手国の公的機関と常に密接な連絡を とり，その協力をえて野外調查を行なった。

1. タイ : Department of Mineral Resources; Rama VI Road, Bangkok

Director-General ; Vija SeTHAPUT

Deputy Director; Saman BuRAvas

Chief, Geological Survey Division; Kaset Pitakpaivan

2. マレーシア : Geological Survey of Malaysia

Geological Survey Federal Headquarter, P. O. Box 1015, Scrivenor Road, Ipoh, Perak

Director ; S. K. Chung (前任者 : J. B. Alexander; W. D. Proctor)

Geological Survey, Borneo Region, Kuching, Sarawak, East Malaysia

Director ; KHo Chin Heng

Geological Survey, Borneo Region, Kota Kinabalu, Sabah, East Malaysia

Director ; David LEE

3. フィリッピン: Bureau of Mines, Herran Street, Manila

Director; Fernando S. Busuego, Jr.

Acting Chief, Petroleum Division; Felipe U. Francisco

4. 中華民国 : 台湾省地質調查所; 台湾省台北市開封街一段一号

所長 : 畢 慶昌 (BIQ Ching Chang) 
5. ECAFE, United Nations - Sala Santitham, Bangkok, Thailand Industries Division (Mineral Resources Development Section); C. Y. LEE, 沢田秀穂

6. USOM (United States Operation Mission to Thailand); USOM Bldg. Phetburi Road, Bangkok

7. 国立台湾大学理学部地質学系

馬 廷英, 林 朝棨

8. 中国石油股份公司 (Chinese Petroleum Corporation)；中華民国台湾省苗栗県

孟 昭葬

9. 在外公館

在夕イ国日本国大使館, Bangkok

在マレーシア国日本国大使館, Kuala Lumpur

在フィリッピン国日本国大使館, Manila

在中華民国日本国大使館，台北市

在 Kota Kinabalu，日本国領事館

\section{IV. 調查地域の概略}

現地調查を行なう際には事前にできる限り情報を集めて効果的に調查をすることが 望ましいことはいう までもない。相手国協力機関でかなりの精度で層序的事実が判明している場合には直ちに生層序的研究に 重点をおく調査を行える場合もあつたが，そうでない場合には一定のルートに沿う概査に止まつたのはや むをえない。

1. 第 1 次調查; 1962年12月 3 日 1963年 1 月 31 日（第 1 図(1)印）

(1) 全員; Rat Buri 地域 [Kaset, Pumwarn, Sangob 参加]

（2）橋本・佐藤・Pumwarn 班; Mae Sot, Li, Mae Moh [Kaset 参加], Mae Fang の各地域

（3）鳥山・勘米良班; Loei-Wang Saphung[小林・Kaset 参加], Sara Buri 地域[Sangob - Angoon 参加了

（4）橋本・鳥山・勘米良・佐藤班; Chumpong 地域 [Pumwarn ・ Angoon 参加]

（5）鳥山・勘米良・佐藤班; Petchabun 地域 [Pumwarn 参加]

2. 第 2 次調查*; 1969 年 12 月 1 日 1964年 2 月 24 日（第 1 図，第 2 図(2)印)

(1) Khorat 班 (岩井・浅間) ; Nakhon Ratchasima, Ban Khok Khli, Ban Kut Bot (Phu Moei), Kalasin-Sakhon Nakhon; Ban Na Yo, Nong Bua Lamphu-Ban Huai Dua, Loei-Dan Sai, Phu Kradung, Huai Hin Lat, Petchabun (Khlong Wang Ang), Lom Sak-Pitsanulok, Li-Thoen, の各地域

（2）Loei 班（佐藤・浜田・猪郷）; Huai Luang, Ban Pha Noi, Huai Bun Nak, Tham Nam Maholan, Phu Pha Sing, Wat Tham Tha Phu, Huai Yee Leurt, Nam Pao,Pha Nok Khao の各地域

（3）半島部班（鳥山・佐藤・浜田・猪鄉）; Phuket-Phangnga-Krabi，Thung Song-TrangSatun, および Ko Muk, Ko Phe Tra, Ko Tarutao, Ko Krang などの西海岸の島々

（4） Langkawi 班（小林・木村・猪郷）；Langkawi 島 (Langgon, Tembus, Singa Besar, Merah, Singa Kechil, Tepok の諸島)

（5）マレー北西部班（猪郷・浜田）; Padang Besar, Perlis, Alor Star の各地域

* 第 2 次調查の報告は KOBAYASHI et al. (1964) 参照 


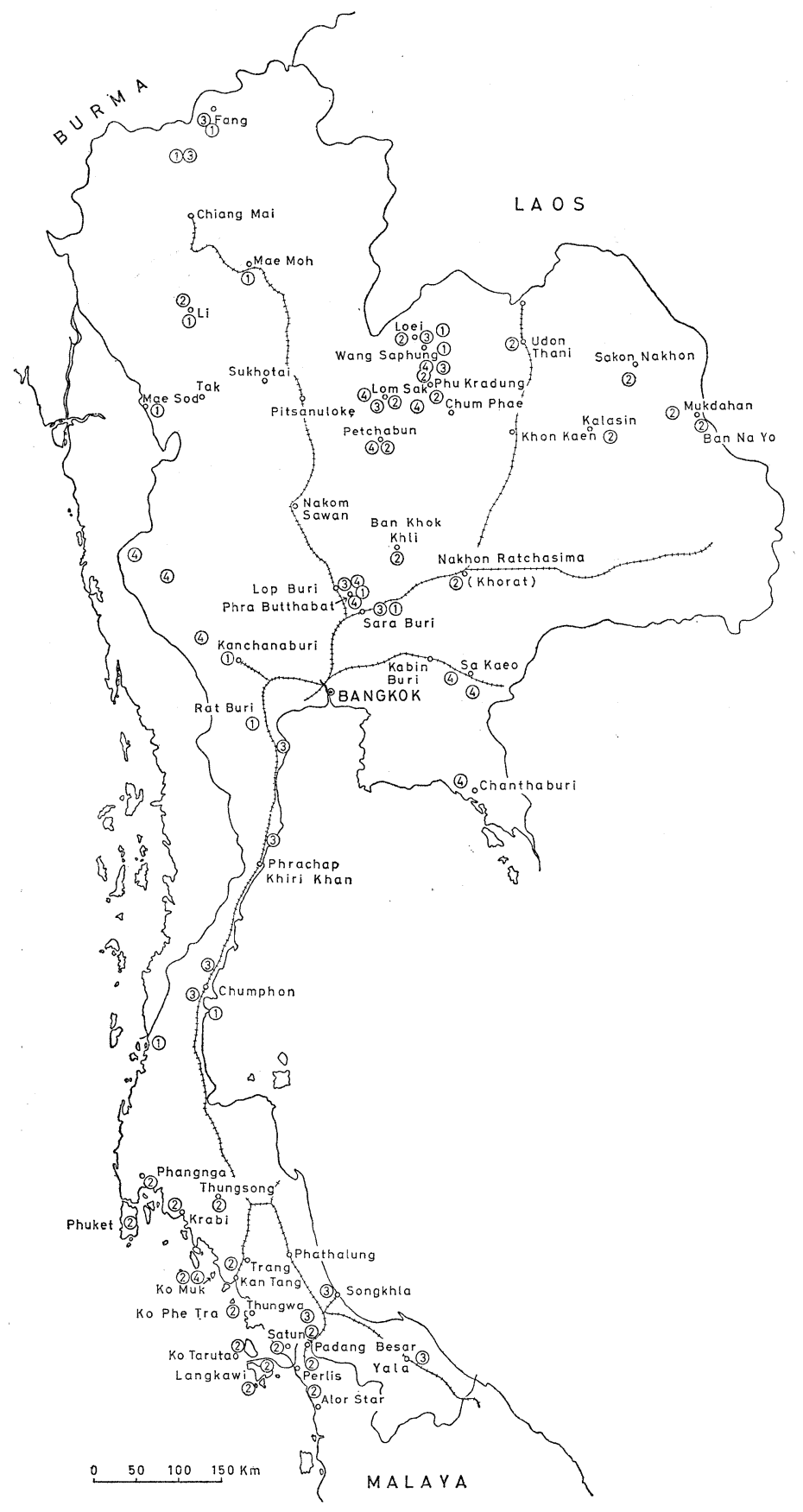

第1図タイに格ける調查地域

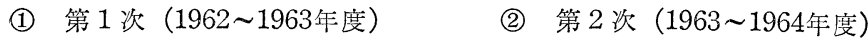

(3) 第 3 次 $(1964 \sim 1965$ 年度) (4) 第 4 次 (1965 1966年度) 


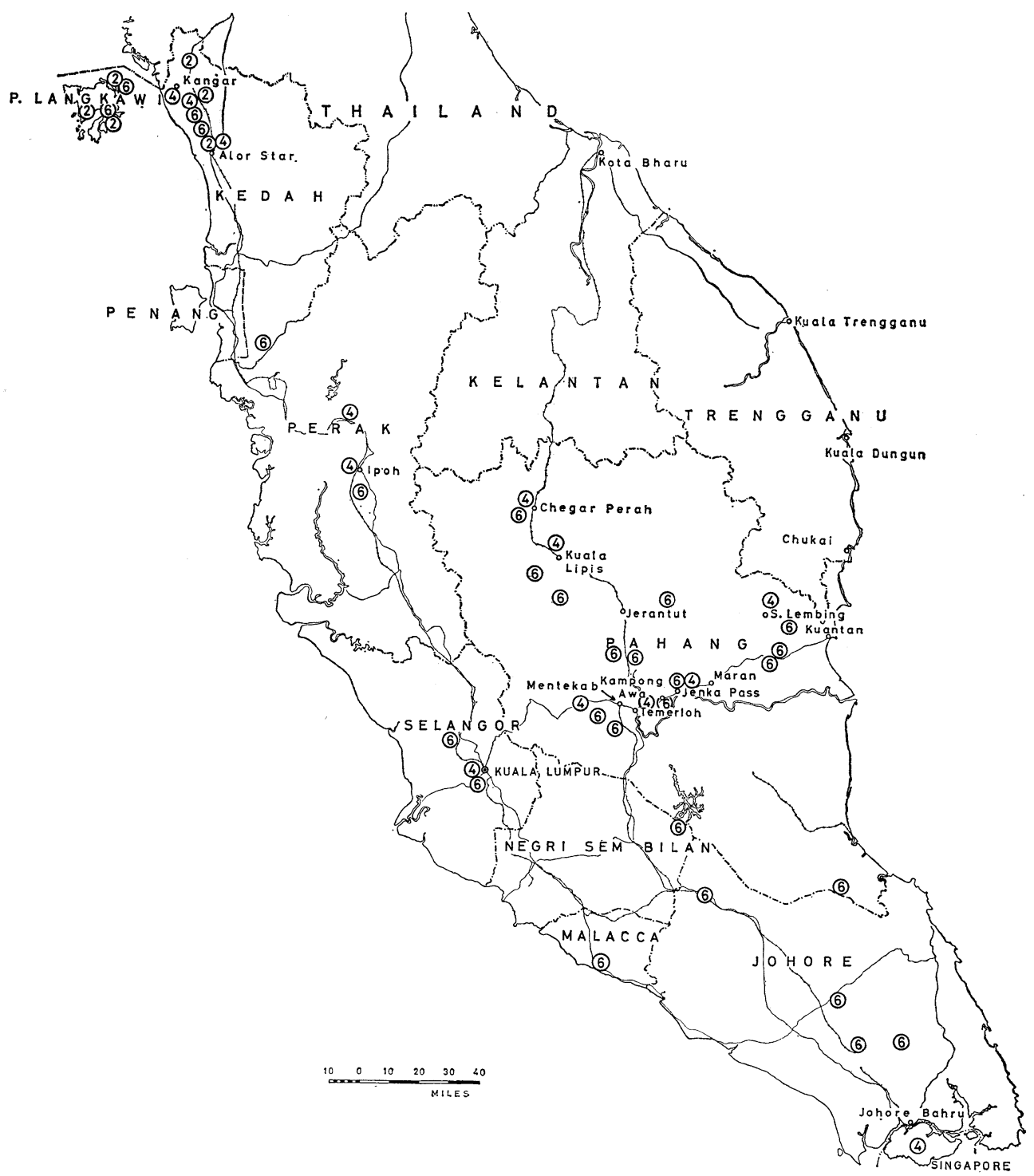

第 2 図 西マレーシアにおける調查地域
(2) 第 2 次調査 $(1963 \sim 1964$ 年度)
(4) 第 4 次調查（1965 1966年度）

(6) 第 6 次調查 $(1968 \sim 1969$ 年度)

3. 第 3 次調査 (第 1 図, 第 3 図(3)印)

（1）フィリッピン班；1964年11月 1 日～12月14日

〔]内は同行した Bureau of Mines の staff

浅野・高柳班; Cebu 島（11月 7 日 19日) [R. Grey, J. EsGUERRA, G. BALCE]

金谷・首藤班 ; Panay 島（11月 7 日 21日） [B. GONZALES, P. SANTOS]

金谷・首藤・高柳班; Luzon 島 Rizal province, Tanay（11月27日), Tarlac 地域, Pampanga 地域（11月28日～12月 3 日） [R. GREY, B. REYES, B. GonZALES] 
（2）タイ班，1964年12月21日～ 1965年 2 月 23 日

鳥山・勘米良班; Phra Phutthabat 地域(1964年12 月29日～1965年1月26日） 勘米良・柳田班; Sara Buri 東方山地（1965年 1 月 29 日 $\sim 2$ 月 12 日）

柳田・猪郷 - 浜田班 : Loei, Lom Sak, Fang の各地域 （1965年1月 6 日～26日） 猪鄉 ・ 浜田班 : 半島部 Songkhla 地域; Yala 地域 (1965年 1 月 30 日 2 月 14 日)

4. 第 4 次調查；1965年11月 12 月; 1966年 7 月 8 月（第 1 図, 第 2 図, 第 3 図(4)印)

(1) フィリッピン班

a . 橋本・佐藤班 ; Mindoro 島南部 (Mansalay 付近, Mansalay-San Jose, Bato Eli 付近), Luzon 島 Legaspi 付近, Marinduque

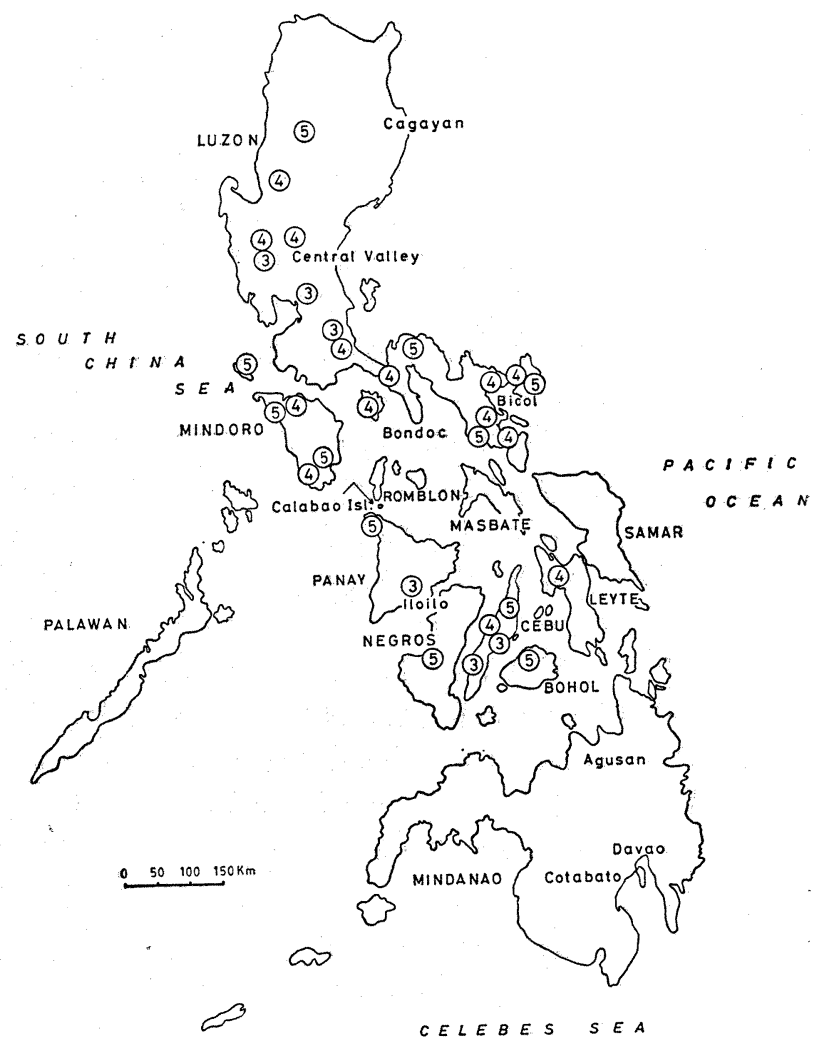
島 Boac など（1965年11月 第3図フィリピンに抢ける調查地域

(3) 第 3 次調查（1964 1965年度）

(4) 第 4 次調查 $(1965 \sim 1966$ 年度) 24 日～12月 22 日）[B. RE，

(5) 第 5 次調查 $(1966 \sim 1967$ 年度) YES, J. EsguerRA, D. ANDAL, J. FERNANDEZ (Marinduque のみ) 参加]

b. 木村・徳山班 ; Luzon 島タルタロ, Tarlac, Baguio 各地域, Tayabas および Lamon 湾地域; Leyte 島北部（1965年12月28日～1966年1月26日）

c. 北村·菅野班; Luzon 島 Tarlac, Baguio 地域, Legaspi, Bicole 地域, Albay 地域; Catanduanes 群島, Caramoan 半島; Cebu 島（1965年12月28日～1966年 1月26日）〔J. ESGUERRA, F. Miranda, E. Gamos 参加]

(2) タイ班

a . 橋本・佐藤班 : Khwae 河流域西部（1965年12月30日～1966年 1 月13日）〔Pumwarn 参加】

b. 鳥山・鞠米良・柳田班; Sara Buri-Lop Buri 地域, [Prayon 参加〕 Kabin Buri-Sa Kaeo 地 域(1965年12月30日～1966年1月14日) [Rakchai，Rucha，Patchara 参加]

c. 岩井・坂上班 : Lom Sak-Pitsanulok 地域, Loei 地域, Chum Pae 地域(1965年12月30日 1966 年1月20日)

d. 柳田・坂上班 : Loei-Petchabun 地域, 西海岸 Ko Muk 島 [Pumwarn 参加]

(3) マレー班 猪郷・田村班; Keroh, Ipoh 付近, Mentekab, Kuantan, Sungei Pahang, Chegar Perah の各 
地域, Singapore 西方地域 (1966年7月15日～8月17日)

5 . 第 5 次調查*(1966年12月 1967年 2 月)（第 3 図(5)印）

（1）浅野班; 台湾東部地域（1966年10月10日～11月20日）

（2）橋本 - 佐藤班; Luzon 島 Mountain 州 [D. MURIEL 参加]; Lubang 島 [D. ANDAL, P. ANDAL, F. GERVASIO 参加]; Mindoro 島北部 (Abra de Ilog Puerto Garela の山中), 同南部 Bongabong, Roxas, Mansalay; Tablas 島; Panay 島 Buruanga 半島 [D. ANDAL, P. ANDAL 参加了(1967年 1月10日～2月20日)

（3）北村 - 小高 - 菅野班; 台湾北部地域; Cebu 島中部, Negros 島南部, Masbate 島中部, Bohol 島, Catanduanes 島, Luzon 島 Albay 盈地, Camarines Norte [F. Miranda, E. GaMos, E. VAllesteros, B. DunA 参加了(1966年11月 8 日 12月20日)

（4）木村・小西班; 台湾中央山脈, 恒春半島（1966年10月10日～11月20日）

6. 第 6 次調査 : 西マレーシア・東マレーシア；1968年１969年（第 2 図，第 4 図(6)印）

(1) 夏季班（1968年 7 月 6 日〜 9 月 9 日）

a. 全員; カンボジヤ Sisophon 石灰岩 (7月 9 日)

b. 首藤・氏家班（鳥山一部参加）; Terbat, Bau-Lundu 間, Melinau 地域, Selidong 地域, Burnei 北部 (Tuton-Seria 間); Selimpopon 地域; Semporna 地域, Sandakan 周辺地域

c. 橋本・田村班**; カンパール, Ipoh-Kuala Lumpur, Fort Iskandar, Temerloh-Kuala LipisKuantan 地域, Chegar Perah 地域; Ipoh-Alor Star, Bukit Kechil, Taiping; Kuchin 南方 地域, Madai cave, Tawao 北西部, Semporna 地域, Sandakan 西方地域, Kudat 地域

(2) 冬季班

A. 猪郷・小池班（1968年11月25日～12月26日）

Ipoh 北方おうび南方地域, Alor Star 北方地域, Langkawi 島, Kuala Lumpur 石灰岩, Benton 南方地域, Seremban 付近, Malacca 北方地域

B. (1969年 2 月 16 日 3 月18日)

a. 全員; Temerloh-Maran 間, Temerloh-Jerantut 間, Mentakab 付近

b. 坂上・柳田 - 小沢班（岩井一部参加）; Kuantan-Sungei Lembing 間, Bukit Charas Bukit Panchin, Sungei Lembing, Chukai, Temerloh-Kampong Awah-Jenka Pass, Kota Jin

c. 岩井・浅間・藤山班; Mentakab 付近, Jenka Pass 付近, Maran 付近, Maran-Kuantan 閒; Sungei Linggiu 付近, Johore-Bahru 付近, Batu Arang 地域, Kluang 付近

\section{V. 室内研究と成果の発表}

\section{1. 討論会および講演会}

このプロジェクトによる現地調查の開始以前に関係協力機関あるいは個人から送付された資料について 研究が行なわれて敌り，それらについて関係各国の研究者とも討論するためにタイ国鉱山資源局で 2 回の 討論会が開かれた。また，このプロジェクトが始まつてからは日本古生物学会例会の際開かれた討論会な ごで成果の公表が行なわれた。

(1) The First Colloqium on the Fossils from Southeastern Asia; December 6, 1962 at the Department of Mineral Resources, Bangkok, Thailand

Opening address By Saman BuRAvas

1. Preliminary notes on the Older Palaeozoic fossils from Peninsular Thailand and the

* 第 5 次調査の詳細は ASANO et al. (1965) 参照

** 橋本 亘 - 田村 実 (1969) 参照 


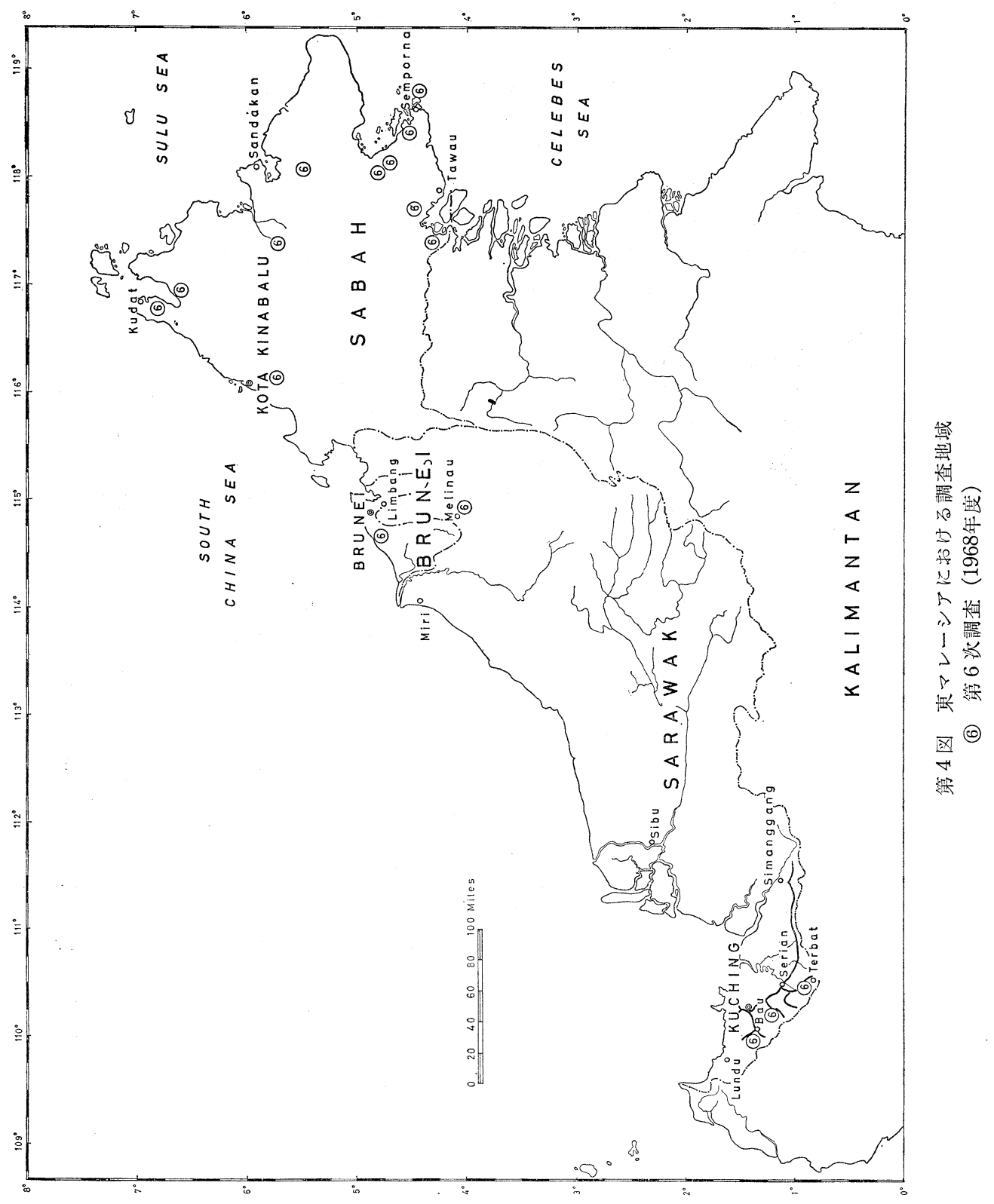


Langkawi Islands. By T. KobaYAshi and T. HAMAdA

2. Fusulinid-bearing rocks in Thailand. By R. TORIYAMA and K. KANMERA

3. Permian Brachiopods from Petchabun area. By J. YANAGIDA (read by KANMERA)

4. On two Carboniferous Brachiopods from Loei. By T. Hamada (read by KoBAYASHI)

5. The Permian Petchabun Flora. By E. Konno (read by KoBAYAshi)

6. Preliminary report on the Palaeozoic Fauna of the Langkawi Islands. By R. TORIYAMA, K. Kanmera, S. SAKAgami, and J. Yanagida

7. Fusulinids from the Rat Buri Limestone at six localities in Thailand. By Kaset Pitakpaivan

8. Triassic Ammonites from Malaya. By T. SAto

9. The Daonella and Halobia Beds in Malaya. By T. KoBAyashi

10. Brief notes on two Jurassic faunas in Viet-nam. By T. SATo and I. HayAmI

11. The Cretaceous Ban Na Yo Fauna of Changwat Nakhon Phanom in the eastern Khorat plateau, By T. KOBAYASHI

12. Some fossils from the Khorat Series. By T. Kobayashi, F. TAKaI and I. Hayami

13. The Palaeogene Li Flora. By S. Endo (read by Hashimoto)

14. Preliminary note on fossil woods from Thailand. By Y. OGURA

15. Preliminary note on Molluscan shells of the Mae Sot and Krabi Series. By L. OyamA (read by Hashimoto)

このコロキュウムは古生物についてタイ国で始めて開かれたものである。

(2) The Second Colloqium on the Geology and Palaeontology of Southeast Asia. December 3rd, 1963 at the Department of Mineral Resources, Bangkok, Thailand

Opening address by Vija SETHAPUT

1. On the occurrence of Middle Ordovician fossils from Satun in Thailand near Malayan Frontier. By T. Kobayashi and T. Hamada

2. Some Middle Ordovician Brachiopods from Satun, South Thailand. By T. HAmadA

3. The Graptolite shale of Thungsong, Thailand. By Charan PoothaI

4. Graptolite shales in North Thailand. By T. KoBAyashi and H. IGO

5. On the Lower Silurian fauna in the Langkawi Islands, Northwest Malaya. By T. Kobayashi, C. R. Jones and T. HAMADA

6. On the new Malayan species of Dalmanitina. By T. Kobayshi and T. Hamada

7. Geology of Loei area, Thailand. By Manas Veeraburus

8. Some Carboniferous Brachiopods from Loei, Thailand. By T. HAMADA

9. Permian Brachiopods from Petchabun area, Central Thailand. By J. YANAGIDA

10. Permian Fusulinid zonation of Sara Buri area, Thailand (Preliminary report). By R. Toriyama, K. Kanmera, Sangob Kaewbidhoon and Agnoon Hongnusonti

11. Two new Permian genera of Fusulinids from Thailand (Preliminary report). By R. TORIYAMA and K. KANMERA

12. Permian Bryozoa from Pulau Kong, the Langkawi Islands, Northwest Malaya. By S. SAKAGAMI

13. Permian fossils from North Pahang, Malaya. By H. IGO

14. Conodonts from South Kelantan, Malaya. By H. IgO and T. KoIkE 
15. Permian Fusulinids from the Triassic conglomerate in Kelantan, Malaya. By H. Igo

16. Chemical analysis of oil from Fang, North Thailand. By W. Hashimoto and S. KuDO

17. On the Older Mesozoic Plants from Wang Saphung (Preliminary report). By E. KONNO and K. ASAMA

18. Aalenian (Lower Jurassic) Ammonites from Mae Sot, Northwest Thailand. by Pumwarn KOMALARJUN and T. SATO

19. Some Jurassic Pelecypods from Viet-nam, donated by Dr. H. FontaINE. By I. HAYAMI (read by SATO)

20. On the occurrence of an Upper Cretaceous Plant in Central Thailand. By S. ENDO (read by KoBAYASHI)

21. A supplementary note on the Li Flora in North Thailand. By S. ENDO (read by KOBAYASHI)

22. On the Younger Tertiary Plants from Mae Sot Basin, West Thailand. By S. Endo (read by KoBAYASHI)

23. A brief note on a Mae Sot Insect. By Y. KurosawA

24. Wan It Lampang Diatomite (Preliminary report). By T. KANAYA

25. Lower Mekong Basin Project. By H. SAWADA

（3）シンポジウム「東南アジア及び中近東の古生物と地史」1965年11月 $6 \sim 7$ 日, 千葉大学文理学部, 留学生部

1. 台湾北港試堀井産白亜紀軟体動物化石の研究…速水 格・松本達郎・橋本 亘

2. 台湾の有孔虫研究の現況…黄 敦友

3. フィリッピン群島, 特に Cebu 島の地質について…浅野 清

4. カンボジア西部の二畳系—シソフォン・バッタンバン石灰岩の層序について…石井健一

5. タイ国コラット高原の中生界…岩井淳一・浅間一男

6. タイ国ペチャブンの二畳紀植物化石…浅間一男

7. Waagenophyllid corals from Thailand $\cdots$ Rucha INGAVAT

8. Rat Buri 石灰岩の紡錘虫化石帯 (予報) …鳥山隆三・勘米良亀齢・柳田寿一

9. 馬来半島西岸におけるノーチラスの死後漂着…浜田隆士

10. インドネシアの石油採鉱と古生物調査…岩佐三郎

11. カフジ油田において対比の鍵となる有孔虫化石…大炊御門経輝

12. アムッド人の発掘…高井冬二・鈴木 尚・鎮西清高

13. タイ・マラヤから日本までの褶曲山脈の層位学的・古生物学的調查研究…⼩林貞一

（4）地学協会関係講演会…1951年 3 月 9 日, 日本都市センター, タイ国地質古生物調查旅行談, 地 学クラブ主催. 1967年 5 月 27 日, 日本都市センター, 地学協会主催

1. 東南アジアの地史古生物学研究……林貞一*

2. タイのラブリ石灰岩…鳥山隆三**

3. フィリッピン：ミンドロ島からカラモアン半島にかけての地質構造…橋本 亘・佐藤 正***

（5）シンポジウム「東南アジアに関する地質・古生物」‥11967年11月 $3 \sim 4$ 日, 東北大学理学部

第 1 部 地質

*小林貞一 (1967), **鳥山隆三 (1967), *** 橋本 亘・佐藤 正 $(1968 \sim 70)$ 参照 
1. Mountain 州 Baguio の Mirador 石灰岩…橋本 亘・佐藤 正

2. Marindique 島の地史への寄与…橋本 亘・佐藤 正

3. ミンドロ島東南海岸の Manslay-Bongabon 付近の第三系…橋本 亘・佐藤 正

4. Reconnaissance survey of the geotectonics around the eastern Philippine Arc at Bisayan Basin $\cdots$ N. Kitamura, S. Kanno \& T. KotakA

5. 台湾・琉球列島と本州の更新統の対比に関する二・三の問題…‥中川夫・林 朝棨

6. 東南アジアの白亜紀赤色砂岩層について…小林貞一

\section{第 2 部 古生物}

7. ルソン島の白亜紀浮遊性有孔虫群 $\cdots \cdots$ 高柳洋吉

8. 北ルソン Mountain 州の始新統とその化石…橋本 亘・佐藤 正

9. Fusulinacean fossils from Thailand. Pt. III. Maklaya, a new Permian Fusulinacean genus from central Thailand $\cdots \cdot \mathrm{K}$. KANMERA \& R. TORIYAMA

10. Rat Buri 石灰岩中の誉虫化石について…坂上澄夫

11. Upper Triassic pelecypods from Singapore $\cdots$ T. KoBAYASHI \& M. TAMURA

12. パナイ島第三系の化石腹足類 $\cdots$...首藤次男

13. 台湾省屈尺付近産貝化石について…菅野三郎・張 麗旭

14. タイワンユメハマグリ…小高民夫

15. 南西諸島及び台湾の第四紀後期石灰岩の年代測定結果 $\cdots$... 小西健二・木村敏雄

\section{2. 刊行物}

第 1 第 6 次の現地調查で採集した資料は龙大な量に達しており，時代的にはカンブリア紀より現世ま でのすべての地質時代, 系統分類的には原生動物から答椎動物までの種々の動物化石䇽よび植物化石と多 くの岩石標本が含まれる。これらの資料は現地調査に従事した研究者以外に多数の專門別の研究者によつ て研究されて打り, また対象によつては協力機関の研究者之協同研究が行なわれている。現在まで国内研 究者 42 名, 外国人研究者 17 名が研究汇従事し, 研究完了の成果は文部省成果刊行費の援助を受け, 東京大 学出版会から “Geology and Palaeontology of Southeast Asia” として刊行されている。現在まで7 巻が発行され, 第 8 巻, 第 9 巻は印刷中である。なお 7 巻のなかにはこのプロジェクトが始まる以前に既 に公表されていた論文, および刊行費の限度があるため他の印刷物に発表された諭文の別刷を合本した巻 もある(下記＊印)

\section{Geology and Palaeontology of Southeast Asia}

Volume $1^{*}, 1964$ 年12月 1 日発行

Geology of Thailand. By T. KoBAYASHI

Palaeontology of Thailand (1916 62), By T. KOBAYASHI

1. On the Cretaceous Ban Na Yo Fauna of East Thailand with a note on the description of Nippononaia, Trigonioides and Plicatounio. By T. Kobayshi (JJGG)

2. Ammonites du Trias de la Malaisie. Par T. Sato (JJGG)

3. On the Triassic Daonella Beds in central Pahang, Malaya. By T. KoBayashi (JJGG)

4. Halobia and some other fossils from Kedah, Northwest Malaya. By T. KoBAyshi (JJGG)

5. Some Permian Plants from Thailand. By E. Kon'No (JJGG)

6. Some Older Tertiary Plants from Northern Thailand. By S. ENdo (JJGG)

7. On Some Mesozoic fossils from the Khorat Series of East Thailand and a note on the Khorat Series. By T. Kobayashi, F. TAKaI and I. Hayami (JJGG)

8. Bryozoa from Pulau Jong, the Langkawi Islands, Northwest Malaya. By S. SAKAGAMI 
(JJGG)

9. Permian Brachiopods from centlal Thailand. By J. YANAGIDA (MKU)

10. Two Carboniferous Brachiopods from Loei, Thailand. By T. HAmadA (JJGG)

11. Permian fossils from northern Pahang, Malaya. By H. IGO (JJGG)

12. On the Lower Silurian shelly fauna in the Langkawi Islands, Northwest Malaya. By T. Kobayashi, C. R. Jones and T. Hamada (JJGG)

13. On a new Malayan species of Dalmanitina. By T. Kobayashi and T. HAMAda (JJGG)

14. Aalenian (Jurassic) Ammonites from Mae Sot, Northwestern Thailand. By P. KomalarJUN and T. SATO (JJGG)

15. Some Lower Jurassic Peleypods from Viet-nam, collected by Dr. H. FonTAIne. By I. HAYAMI (JJGG)

16. On the Middle Ordovician fossils from Satun, the Malaysian Frontier of Thailand. By T. Kobayashi and T. HAMAda (JJGG)

17. Some Middle Ordovician Brachiopods from Satun, Southern Thailand By T. HAMAdA (JJGG)

Volume 2*，1969年12月17日発行

18. On the occurrene of Graptolites in North Thailand. By T. KoBAYASHI and H. IGo(JJGG)

19. Three Carboniferous species of Bryozoa from Khao Noi, Central Thailand. By. S. SAKAGAMI (JJGG)

20. Nautilus pompilius drift on the west coast of Thailand. By R. ToriYama, T. Sato, T. HAMAda and P. Komalarjun (JJGG)

21. Notes on the drifted Nautilus in Thailand. By T. HAMAdA (SPUT)

22. Fusulinids of the Rat Buri limestone of Thailand. By K. Pitakpaivah (MKU)

23. Triassic Conodonts from Kelantan, Malaya. By H. IGO, E. H. YIN and T. KoIKE (MMG)

24. Stratigraphy of the so-called Khorat Series and a note on the fossil plant-bearing strata in Thailand. By J. Iwai, K. Asama, M. Veeraburus and A. Hongnusonthi (JJGG)

25. Permian Plants from Petchabun, Thailand and problems of floral migration from Gondwana land. By K. AsAma (BNSM)

26. A new Proetoid Trilobite from Perlis, Malaysia (Malaya). By T. KobaYashi and T. Hamada (JJGG)

27. Permian Bryzoa fauna of Ko Muk, Peninsular Thailand. By S. Sakagami (JJGG)

28. The Cyclostomatous Bryozoa from Ko Muk, Peninsular Thailand. By S. Sakagami (JJGG)

29. Calcareous Algae from Thailand. By R. Endo (JJGG)

30. Caboniferous Bryozoa collected by Kaset PitakPaivan at Khao Kok, Changwat Rat Buri, Thailand. By S. SAKAGAMI (JJGG)

31. Some Late Mesozoic and Tertiary plants and a fossil Insect from West Thailand. By S. ENDo and I. Fujtyama (JJGG)

Summary of fossil record in Malaya and Singapore 1900 1965. By C. R. JonES, D. J. GobBETT and T. KOBAYASHI

Volume 3，1967年 3 月24日発行

32. Ordovician and Silurian Conodonts from the Langkawi Islands, Malaya. By H. IGO and T. KOIKE 
33. Some Permian Fusulinids from Pahang, Malaya. By H. IGO

34. On the Palaeozoic Bryozoa collected by R. D. Stewart, near Petchabun, Thailand. By S. SAKAGAMI

35. Early Permian Brachiopods from North-central Thailand. By J. YANAGIDA

36. The Daonella and Halobia facies of the Thai-Malay Peninsula compared with those of Japan. By T. Kobayashi, C. K. Burton, A. Tokuyama and E. H. Yin

37. Geological structures in the northeastern and southern parts of the Langkawi Islands, Northwest Malaya. By T. Kimura and C. R. JONES

38. Some Younger Mesozoic plants from Malaya. By E. KNo'No

39. A supplementary note on the Palaeogene Li flora in North Thailand. By S. ENDO

Volume 4, 1968年 3 月18日発行

40. Ordovician and Silurian Conodonts from the Langkawi Islands, Malaya, Part II. By H. IGO and T. KOIKE

41. A Devonian Phacopid recently discovered by Mr. Charan Poothai in Peninsular Thailand. By T. Kobayashi and T. Hamada

42. Fusulinacean fossils from Thailand, Part II. Two new Permian genera from Thailand. By R. TORIYAMA and K. KANMERA

43. Permian Bryozoa from Khao Phrik, near Rat Buri, Thailand. By S. SAkagami

44. Permian Bryozoa from Khao Chong Krachok, Penisular Thailand By S. SAKAgAmI

45. Permian Plants from Loei, Thailand. By K. Asama, J. Iwai, M. Veeraburus and A. HONGNUSONTHI

46. Some non-marine Bivalves from the Mesozoic Khorat Group of Thailand. By I. HayamI

47. The Cretaceous non-marine Pelecypods from the Nam Phung Dam site in the northeastern part of the Khorata plateau, Thailand, with a note on the Trigonioididae. By T. KOBAYASHI

48. Addition to some Younger Mesozoic Plants from Malaya. By E. Kon'NO

49. Geologic structures in the Tayabas Isthmus district, Philippines. By T. KImURA, A. Tokuyama, B. A. Gonzales and D. R. Andal

50. The Jurassic Mansalay Formation, Southern Mindoro, Philippines. By D.R. ANDAL, J. S. EsguerRa, W. Hashimoto, B. P. Reyes and T. Sato

51. Fusulinid-bearing limestone pebbles found in the Agbahag conglomerate Mansalay, Oriental Mindoro, Philippines. By T. Kolke, W. Hashimoto and T. SATo

52. Fossil Algae from Mindoro Oriental Province, Mindoro Island, the Philippines. By R. ENDO

Volume 5, 1968年12月25日発行

53. Swaicoelia, a new Ambocoeliid genus (Brachiopoda) from North Thailand. By T. HAMADA

54. Ambocoeliids from Red Beds in the Malayan Peninsula. By T. Hamada

55. Carboniferous Conodonts from Kuantan, Malaya. By H. IGO and T. KoIkE

56. Fusulinacean fossils from Thailand, Part III. Maklaya, new generic designation for Neoschwagerinids of the group of Cancellina pamirica Leven. By K. KANMERA and R. TORIYAMA

57. Permian Bryozoa from Khao Ta Mong Rai, Peninsular Thailand. By S. SAKAgamI 
58. On the source rock of Mae Fang oil field, Chiangmai, North Thailand. By W. HASHIMoto, S. Buravas and S. Kudo

59. Claraia from North Malaya, with a note on the distribution of Claraia in Southeast Asia. By M. TAMURA

60. Myophoria (s.1.) in Malaya with a note on the Triassic Trigoniacea. By T. KoBAYASHI and M. TAMURA

61. Upper Triassic Pelecypods from Singapore. By T. Kobayashi and M. Tamura.

62. Mesozoic stratigraphy of the northwestern part of the Khorat plateau, Thailand. By J. IWAi, S. SAKAGAMI, N. NAKORNSRI, and W. YUYEN

63. The sedimentary structures observed in the rocks of the Khorat Group and overlying formation. By J. IWAI

64. Some Jurassic Bivalves from Mindoro. By I. HAYAMI

65. Preliminary notes on the geotectonics of the Eastern Philippine Arc and the Visayan Basin. By N. Kitamura, T. Kotaka and S. Kanno

66. Contribution to the geology of Mindoro and neighboring islands, the Philippines. By W. HASHIMOTO and T. SATO

67. ${ }^{234} \mathrm{U}^{230}$-Th dating of some Late Quaternary coralline limestones from southern Taiwan (Formosa). By K. Konishi, A. OMURA and T. Kimura

Volume 6*, 1969年11月 5 日発行

68. Neogene Gastropods from Panay Island, the Philippines. By T. SHUTO (MKU)

69. Late Palaeozoic Brachiopods from Red Beds in the Malayan Peninsula. By T. HamadA

70. Fusulinacean fossils from Thailand, Part IV. On some Permian Fusulinaceans from Peninsular Thailand By S. SAKAGAMI

71. Tertiary and Pleistocene Algae from Mindoro, the Philippines. By W. Hashimoto

Paleontology of the Philippines. By W. Hashimoto

Volume 7，1970年 1 月19日発行

72. Devonian Brachiopods from Kroh, Upper Perak in Malaysia (Malaya.) By T. HAMAdA

73. Fusulinacean fossils from Thailand, Part V. Neofusulinella from Thailand. By R. TORIYAMA, K. KANMERA and R. INGAVAT

74. Fossil Algae from the Khao Phlong Phrab district in Thailand. By R. ENDO

75. Discovery of Distichoplax biserialis (DIETRICH) in Upper Eocene limestone lenses exposed in the valley of the Mangamnan River, Marinduque Island, the Philippines. By W. IsHiJIMA and W. HASHIMOTO

76. Miocene Cyprinid Fishes from Mae Sot Basin, Northwestern Thailand. By T. UYENO

77. Heavy minerals of the Miocene Singit and Tarao Formations in Panay Island, the Philippines. By J. OHARA

Volume 8，(1970年12月 5 日発行)

78. A Cyclopygid-bearing Ordovician faunule discovered in Malaya with a note on the Cyclopygidae. By T. KoBAyAshI and T. HAMADA

79. Fusulininan fossils from Thailand, Part VI. Variation and relative growth of Colania douvillei (OzAwA) from the Rat Buri Limestone. By T. OzAwA

80. Addition to the Permian Bryozoa from Ko Muk, Peninsular Thailand. By S. SAKAgAMI 
81. Permian Brachiopods from Khao Phrik near Rat Buri, Thailand. By J. YANAGIDA

82. Some Permian Plants from the Jenka Pass, Pahang, West Malaysia. By E. Kon'NO and K. ASAMA

83. Pteriacea from Malayan Triassic. By M. TAMURA

84. Tertiary calcareous Algae from Marinduque Island, the Philippines. By W. HASHImoto

85. Miocene Foraminiferal faunas from the Sandakan Formation, North Borneo. By H. UJIIE

86. Larger Foraminifera from the Philippines, Part I. By S. Hanzawa and W. Hashimoto

87. Yabeostroma philippinensis gen. et sp. nov. from Southern Occidental Mindoro, Mindoro Island, the Philippines. By W. HASHIMOTO

88. Studies of the Younger Cenozoic deposits in Taiwan (Formosa), Part 1. The Younger Cenozoic deposits of the middle part of West Taiwan. By W. Hashimoto, K. TAIRA, K. KURIHARA and Y. MAKINO

89. The structural relation of the Taitung coastal range with the central range of Taiwan. By T. Kimura, T. P. YEN and K. KONISHI

上記第 $1 ， 2 ， 6$ 巻の各論文の終りの（）内にそれぞれの論文の出所を略号で示した。

JJGG ; Japanese Journal of Geology and Geography

MKU ; Memoirs of the Faculty of Science, Kyushu University, Series D, Geology

SPUT ; Scientific Papers of the College of General Education, University of Tokyo

MMG ; Memoirs of the Mejiro Gakuen Woman's Junior College

BNSM ; Bulletin of the National Science Musium

定価: Vol. 1， $¥ 2800$; Vol. 2，3，¥3500；Vol. 4 7，¥5000；Vol. 8. ¥7000

第 2 表 Geology and Palaeontology of Southeast Asia, vols. 1-8(1964-1970) の揭載諭文の專門分野別分布

\begin{tabular}{|c|c|c|c|c|c|c|c|c|c|c|c|c|c|c|c|}
\hline 92 & 計 & 10 & 1 & 10 & 9 & 12 & 4 & 4 & 1 & 4 & 1 & 14 & 11 & 6 & 5 \\
\hline 計 & 時代 & 原生 & 腔腸 & 鮌虫 & 腕足 & $\begin{array}{l}\text { 交足 } \\
\text { 腹足 }\end{array}$ & 頭足 & 三葉虫 & 筆石 & 錐歯 & 脊椎 & 植物 & $\mid$\begin{tabular}{|l|}
$\mid$ 生物群 \\
地史
\end{tabular} & 堆積 & 糗造 \\
\hline 3 & $Q-R$ & & & & & & 2 & & & & & & 1 & & \\
\hline 2 & $T-Q$ & & & & & & & & & & & 1 & & 1 & \\
\hline 10 & $\mathrm{~T}$ & 2 & 1 & & & 1 & & & & & 1 & 4 & & 1 & \\
\hline 1 & $\mathrm{~K}-\mathrm{T}$ & & & & & & & & & & & & 1 & & \\
\hline 4 & $\mathrm{~K}$ & & & & & 2 & & & & & & 2 & & & \\
\hline 3 & $J-K$ & & & & & & & & & & & 1 & & 2 & \\
\hline 6 & $\mathrm{~J}$ & & & & & 3 & 1 & & & & & 1 & & 1 & \\
\hline 9 & $\operatorname{Tr}$ & & & & & 6 & 1 & & & 1 & & & 1 & & \\
\hline 23 & $\mathrm{P}$ & 8 & & 7 & 3 & & & & & & & 4 & 1 & & \\
\hline 4 & $\mathrm{C}$ & & & 3 & 1 & & & & & & & & & & \\
\hline 4 & $D-C$ & & & & 2 & & & 1 & & 1 & & & & & \\
\hline 3 & D & & & & 2 & & & 1 & & & & & & & \\
\hline 3 & $\mathrm{~S}$ & & & & & & & 1 & 1 & & & & 1 & & \\
\hline 2 & $\mathrm{O}-\mathrm{S}$ & & & & & & & & & 2 & & & & & \\
\hline 3 & $\mathrm{O}$ & & & & 1 & & & 1 & & & & & 1 & & \\
\hline 0 & $\mathrm{Cm}$ & & & & & & & & & & & & & & \\
\hline 12 & Misc & & & & & & & & & & & 1 & 5 & 1 & 5 \\
\hline
\end{tabular}


第 3 表 Geology and Palaeontology of Southeast Asia, vols. 1-8 (1964-1970) の揭載論文の国別論文数，（）内は共著者の当該研究者数

\begin{tabular}{|c|c|c|c|c|c|c|c|c|}
\hline 国別 & \& 1 & $\begin{array}{l}\text { 西マレ } \\
\text { ーシア }\end{array}$ & $\begin{array}{l}\text { シンガ } \\
\text { ポール }\end{array}$ & $\begin{array}{l}\text { 東マレ } \\
\text { ーシア } \\
\end{array}$ & $\begin{array}{l}\text { ヴェト } \\
\text { ナム } \\
\end{array}$ & 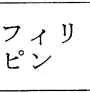 & 台 湾 & 計 \\
\hline 1 & $11(1)$ & $7(1)$ & & & 1 & & & $19(2)$ \\
\hline 2 & $12(3)$ & $3(2)$ & & & & & & $15(5)$ \\
\hline 3 & 3 & $5(2)$ & & & & & & $8(2)$ \\
\hline 4 & $7(1)$ & 2 & & & & $4(2)$ & & $13(3)$ \\
\hline 5 & $6(2)$ & 4 & 1 & & & 3 & 1 & $15(2)$ \\
\hline 6 & 1 & 1 & & & & 3 & & $5(0)$ \\
\hline 7 & $3(3)$ & 1 & & & & 2 & & $6(1)$ \\
\hline 8 & 3 & 2 & & 1 & & 3 & $2(1)$ & $11(1)$ \\
\hline 計 & $48(8)$ & $25(6)$ & 1 & 1 & 1 & $15(2)$ & $3(1)$ & $92(16)$ \\
\hline
\end{tabular}

以上 8 巻の專門分野別, 地域別について, 浜田（1969）が第 $1 \sim 5$ 巻についてまとめた 表にその後の 3 巻分を加えたものも第 $2 ， 3$ 表に示す。なお，現在研究進行中のものが多数あり，その全部を原著論文と してこの刊行物に公表することは経費上無理の場合があるので，上記第 1 巻・第 2 巻・ 6 巻（一部）のよ らに他の刊行物に原著として発表したものの別刷を合本, あるいは別刷と原著とを合せて1巻にして刊行 することも予定されている。

\section{VI. 参考事項}

\section{1. 地形図}

地質調查に地形図が不可欠なことはいうまでもないが，地形図を自由に入手することができる日本と違 い，異なる政治体制の国が隣り合せになつているところでは地形図はあつても入手困難な場合がある。

(1) タイ：かなりの部分に航空写真をもとにした正確な 2 色刷りの 5 万分の 1 地形図があるが市販さ れていない。Department of Mineral Resourcesには勿論保管されている。一般的な road map は Shell あるいは Esso などが作っているので大きなガソリンスタンドで手に入ることもある。

（2）マレーシア： 1 inch： 1 mile の地形図があるが市販されていない。ただし, 使用目的を明記 し, 警察の許可を受けて Land and Survey で購入でき, 持ち帰りもできる。しかしこの許可を得るには かなりの日数が必要である。自動車用の road map は Mobile, Shell などのものが利用できる。

(3) フィリッピン：5 万分の 1 地形図が市販されている。

（4）台湾: 準戦時体制下にあるため厳重な統制下におかれていたが，最近市販されるようになつた由 である。

\section{2. 地質図}

ぞの程度の地質図が発行されているかはその国の文化のバロメーターになるともいわれている。

（1）タイ：1953年 (BROWN et al.) に発行された250万分の1の地質図があり, 最近改訂版がでた由 である。スケールの大きい地質図は local geology の報告書についている地質図が若干あり，また鉣物資 源局の未発表資料にもかなりあるが，タイ語で書かれているので利用困難である。現在ドイツ地質調査所 と鈗物資源局との契約で，大スケール（20万分の 1 ? ）の地質図幅作製のため，すでに数年間調査が進め られているが，図幅はまだ刊行されていない。(German Geological Mission to Thailand； c/o German Embassy, 64 Petchburi Road, Bangkok).

（2）マレーシア : 西マレーシア (マラヤ) 全体の地質図はマレー地質調査所によって1935年以来何回 
か発行され，1963年に発行された第 6 版の50万分の 1 地質図が 最も新らしい。(ただし塗色がどぎっく, きわめて見にくい), スケールの大きい地質図 (63360分の 1) は20数枚発行され, 購入可能である。詳し いことは GOBBETT (1968) の文献集を参照されたい。東マレーシア（サラワク・サバ）でも50万分の 1 地 質図（1967年）が発行されている。

（3）フィリッピン：全体の 地質図は Bureau of Mines から1963年に 発行された100万分の1地質図 （全体で 8 枚）がある。スケールの大きい地質図は部分的に報告書の付図などについているものがあり， また石油会社がかなり詳しい data に基づいた図をもつていると思われるが，一般的な利用は困難であ る。

（4）台湾：全体の30万分の 1 地質図は1953年に台湾省地質調查所から発行され，入手可能である。現 在新版の出版準備中の由である。 5 万分の 1 地質図は第 5 号 (大屯山), 第 9 号 (台北), 第10号 (瑞芳) が1953年に台湾省地質調查所から刊行されている。日本領時代要塞地帯であつた地域は白ぬきのままにな つているところもある。油田地帯の地質図は「台湾石油地質」に多く出ており, 炭田地帯の地質は地質調 查所彙報にみられる。

\section{謝 辞}

このプロジェクトが順調に行なわれ，現在なお進行しつつあるのは研究者一同の熱意によることはいう までもないが，それぞれの目的地域において心からなる協力を惜しみなく与えられた現地協力機関 (IIIに列 記した)の Director 以下多くの staffに心からの謝意を捧げる。またIII. 9 に列記した在外公館からは多く の便宜供与を受けた。またこの計画の発足に当つて茅誠司東大名誉教授からアジア財団へ紹介して頂いた。 深く謝意を表する。またこのプロジェクトの海外調查費を支給されたアジア財団, 海外技術協力事業団, 文 部省 (科学研究費・海外学術調査費), および多くの援助を下さつた下記の公共団体㧍よび会社に深謝する

旭ガラス株式会社

旭化成株式会社

同和鉱業株式会社

富士電機株式会社

古河鉱業株式会社

日野自動車株式会社

日立ファミリーセンター（福岡）

石原産業株式会社

北スマトラ石油開発協力株式会社

鋼管鈗業株式会社

九州電力株式会社

九州石油開発株式会社

明治鉱業株式会社

三菱金属鉱業株式会社

三菱鈗業株式会社

三井金属鉱業株式会社

三井鉱山株式会社

南洋物産株式会社

日本鉱業株式会社

日本航空株式会社
日本セメント株式会社

日鉄鉣業株式会社

小野田セメント株式会社

サンコー・コンサルタント株式会社

三扇コンサルタント株式会社

石油資源開発株式会社

石灰石鈗業協会

白石工業株式会社

住友金属鉱業株式会社

住友石炭株式会社

秋芳町

武田薬品工業株式会社

帝国石油株式会社

東邦亜鉛株式会社

東京地学協会

東京芝浦電気株式会社

八幡製鉄株式会社

安川電機製作所株式会社

(以上 $\mathrm{ABC}$ 順)

付図の製図には九大理学部地質学教室早川惺子さんの手をわずらわした。厚く御礼申しあげる。 


\section{参考文献}

1) AsANo, K. et al. (1965) : Record on the palaeontological reconnaissance work of the Philippines, 1964. Sci. Repts. Tohoku Univ., 2nd Ser. (Geol.), Vol. 37, No. 1, 79-87.

2) BROWN et al. (1953) : Geologic reconnaissance of the mineral deposits of Thailand. Royal Dept. Mines, Geol. Surv. Mem. 1, 1-183, pls. 1-20.

3) GobBet, D. J. (1968) : Bibliography and index of the geology of West Malaysia and Singapore. Bull. Geol. Soc. Malaysia, No. 2, 1-152.

4) GobBetr, D. J. (1970) : Bibliography and index of the geology of West Malaysia and Singapore-Supplement 1968. Ibid. Bull. No. 3.

5）浜田隆士 (1969)：米・ソ・古生物学の動向. “化石”第18号, 68-82.

6) 橋本 亘 (1963)：タイ国の石灰岩. “石灰石”第82号, 63-69.

7) 橋本 亘・佐藤 正 (1968 70)：比律賓群島地質構造の研究への寄与(前篇・後篇 I ・ II). 地学 雑誌，第77巻，第 2 号，18-56；第78巻，第 4号，1-36；第79巻，第 1号，1-27.

8) 橋本 亘・田村 実 (1969)：マレイシア地質古生物現地調査報告-1968.7.7-1968.9.9一. 熊本 大学教育学部紀要第 17 号第 1 分冊 (自然科学)，34-50.

9) Kobayashi, T. et al. (1964) : Report of the stratigraphical and palaeontological Reconnaissance in Thailand and Malaya, 1963-1964. Overseas Technical Cooperation Agency, Ref. No. 20, Aug. 1964. (Mimeographed).

10) 小林貞一(1962)：東南アジア産化石の研究, 採集と飼育 24 巻.

11）小林貞一 (1967) : 東南アジアの地史・古生物の研究. 地学雑誌，第76巻，第 4 号，1-12.

12) 鳥山隆三 (1967)：タイのラブリ石灰岩. 地学雑誌，第76巻，第 4 号，13-20.

後記 本稿は鳥山隆三の原稿に小林貞一・岩井淳一・浅野清・橋本亘・浅閒一男が加筆訂正した, 文責 は鳥山にある。

\section{追記 1 .}

鳥山隆三 (1971), 東南アジアに発達する赤色盈地の地史学的古生物学的研究について〔昭和43年度科 学研究費・海外学術調查賈による研究]学術月報 23 巻 11 号 ( 2 月号) 通算 295 号参照

\section{追記 2 .}

Geologial Map of Thailand, 縮尺百厅分の 1, 1969.

Department of Mineral Resources, Ministry of National Development.

カンブリア紀の Tarutao 層群, シルリアー石炭紀の Tanaosi 層群, その上部の Kaeng Krachan

層, 海成三畳紀の Lampang 層群などの新層名があり, コラット層群から海成三疊系を分離してい

る。火成岩類は時代を附して, 細分されている。そして地層・岩類の分布は前のものと比心゙て, 遙か に詳しくなつている。 小林 貞一記 